\title{
The role of markets and policies in delivering innovation for climate change mitigation
}

\author{
Richard G. Newell ${ }^{*}$
}

\begin{abstract}
This paper identifies market incentives and international and domestic policies that could technologically alter energy systems to achieve greenhouse gas stabilization targets while also meeting other societal goals. I consider the conceptual basis and empirical evidence on the effectiveness and efficiency of climate technology policies. The paper reviews the literature on trends and prospects for innovation in climate change mitigation and examines the evidence on induced innovation and the implications for the choice of technology policy. I then consider the impact of technological advances on the environment, the role of direct government support for $\mathrm{R} \& \mathrm{D}$, and the complementarities between policies internalizing environmental externalities and those aimed at environmental innovations.
\end{abstract}

Key words: innovation, technology, R\&D, climate change, energy, policy

JEL classification: O31, O38, Q54, Q58

\section{Introduction}

There are (at least) two key market failures that must be addressed in the response to climate change. As is well understood, there is the environmental externality of greenhouse-gas (GHG) emissions, because there is little private incentive to reduce GHGs. The absence of an appropriate price signal has implications for climate technology innovation and adop-

*Duke University, e-mail: richard.newell@duke.edu

Richard G. Newell completed this paper as the Gendell Associate Professor of Energy and Environmental Economics at the Nicholas School of Environment, when he was also a Research Associate at the National Bureau of Economic Research and a University Fellow at Resources for the Future. He is currently on leave from Duke University as Administrator of the US Energy Information Administration (EIA). The views expressed herein should not be construed as representing the views of EIA or the US Department of Energy. This paper draws heavily from recent overviews and reviews of technology innovation, especially Popp et al. (2009), Gillingham et al. (2008), and Newell (2008, 2009). Special thanks to the co-authors in those collaborations: Kenneth Gillingham, Adam Jaffe, William Pizer, David Popp, and Robert Stavins. Additional thanks for excellent comments from the editor Cameron Hepburn and from Robert Hahn.

doi: $10.1093 /$ oxrep/grq009

(C) The Author 2010. Published by Oxford University Press.

For permissions please e-mail: journals.permissions@oxfordjournals.org. 
tion because, if there is no demand for GHG reductions, then the demand for GHG-reducing technologies will also be too low. In turn, there will be insufficient incentive for companies to invest in mitigation technology research and development (R\&D), because there will be little market demand for any innovations that might come of it. Economists most often point to a market-based emissions policy that places a price on GHGs - through either a cap-andtrade system or an emissions tax - as a cost-effective response to this problem.

Second, and the central focus of this paper, there is a well-understood market failure that leads to underinvestment by industry in R\&D, especially basic research (Goulder, 2004; Jaffe et al., 2005; Newell, 2008; Arrow et al., 2009). Knowledge, just like a stable climate, is a public good; it is well known that individual companies cannot capture the full value of investing in innovation. That value tends to spill over to other technology producers and users, thereby diminishing individual private incentives for R\&D; this problem tends to worsen the more basic and long term is the research. Therefore, well-targeted policy that boosts the level of innovation for climate mitigation technology through R\&D and other innovation policy mechanisms has the potential to lower the overall cost of attaining long-term climate goals.

Given the scale of energy infrastructure investment expected over the coming decades, the pay-off from clean energy technology innovations could be immense. For instance, the International Energy Agency (IEA) projects that about \$22 trillion of investment in energysupply infrastructure will be needed over the 2006-2030 period, or almost $\$ 900$ billion annually, on average (IEA, 2007b). Relative to this baseline investment, the Secretariat of the United Nations Framework Convention on Climate Change (UNFCCC) estimates that an additional $\$ 200$ billion in global investment and financial flows will be required annually by 2030 just to return GHG emissions to current levels (UNFCCC, 2007).

Plausible developments in energy efficiency, advanced bioenergy, wind and solar, nuclear and low-emitting fossil-fuel technologies could greatly reduce these costs. For example, several studies find that the cumulative costs of achieving a given stabilization target might be reduced by 50 per cent or more with technological advances (see, for example, Manne and Richels, 1992, and Clarke et al., 2006). These cost reductions, in turn, translate to economic benefits of hundreds of billions to trillions of dollars globally (Newell, 2008). While one might reasonably argue over detailed modelling assumptions, these and other results demonstrate that technological advance has the potential to significantly decrease the costs of attaining societal goals for climate change mitigation.

Are we spending enough on clean energy technological innovations? Nations currently spend about $\$ 1$ trillion globally each year on R\&D, with more than 95 per cent occurring in the OECD countries, Russia, and China - and 80 per cent in countries represented in the G8 (OECD, 2008; Newell, 2009a). Although innovation activities are not limited to R\&D, R\&D remains one of the few well-tracked indicators of innovative activity and is highly correlated with other indicators. Industry is by far the largest player in R\&D effort, funding more than 60 per cent and performing almost 70 per cent of R\&D globally in 2006 (the most recent year for which complete data are available). Industrial R\&D focuses on applied research and especially development, stimulated by market demand for technologically advanced products and processes. Government is the second largest funder of R\&D globally, at 30 per cent.

Estimates show that private-sector investments in energy R\&D, however, have fallen significantly in real terms since peaking around 1980, in tandem with declines in energy prices and public energy R\&D spending (Figure 1). Research also suggests that the total level of funding is far lower than what is desirable to confront current energy challenges, and that R\&D alone will not solve the problem. In the United States, a strategy summarized by 
Figure 1: Public energy R\&D spending in IEA countries (1974-2006).

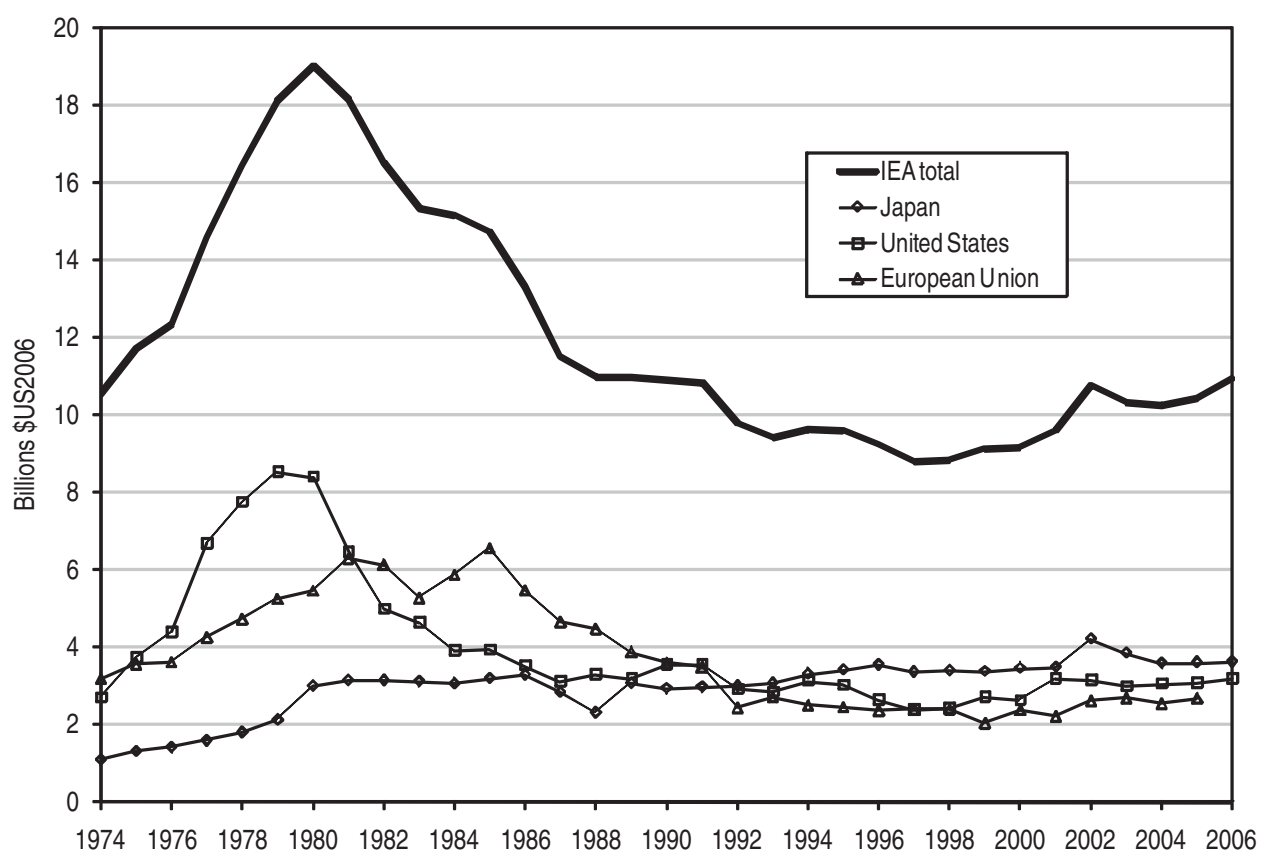

Data source: IEA (2007a). Other IEA governments spend less than $\$ 500 \mathrm{~m}$ annually on energy R\&D.

Newell (2008) suggests that doubling US federal spending on climate mitigation R\&D from 2007 levels to roughly US\$8 billion over several years is consistent with reasonable assumptions about expected GHG mitigation costs, the prospects for R\&D to lower those costs, and thus the rate of return to such R\&D. Similarly, recent IEA (2008) and UNFCCC (2007) assessments suggest at least a doubling of public clean-energy R\&D spending among developed nations within the next several decades.

This paper examines the most important international and domestic policies that could technologically alter energy systems to achieve GHG stabilization targets while also meeting other societal goals. It considers the conceptual basis and empirical evidence on the effectiveness and efficiency of climate technology policies. The paper reviews the literature on trends and prospects for innovation in climate change mitigation. Section II examines the evidence on induced innovation and the implications for the choice of technology policy. Section III considers the impact of technological advances on the environment. The role of direct government support for R\&D is examined in section IV. Section V looks at the complementarities between policies internalizing environmental externalities and those aimed at environmental innovations. Section VI concludes.

\section{Induced innovation}

Because externalities complicate the process of environmentally friendly technological change, market forces provide insufficient incentive for either the creation or adoption of 
low-GHG technologies absent environmental policies. Thus, much research has focused on how environmental policy affects these incentives for both the creation and adoption of environmental technology. This section reviews the literature linking environmental policy and innovation, particularly with regard to climate change.

The concept of induced innovation recognizes that $\mathrm{R} \& \mathrm{D}$ is a profit-motivated investment activity. Higher relative prices for the fruits of innovation will therefore increase the amount of innovative activity. Since environmental policy implicitly or explicitly makes environmental inputs more expensive, the 'induced innovation' hypothesis suggests an important pathway for the interaction of environmental policy and technology, and for the introduction of impacts on technological change as a criterion for evaluation of different policy instruments.

Innovation generated by policies that establish a GHG emission price is sure to come from a wide array of businesses currently engaged in the development and use of energy producing and consuming technologies, especially in the provision of electricity and transportation services. It will also come from the agro-biotech sector (e.g. biofuels and sequestration), from companies that produce and consume other non-carbon-dioxide $\left(\mathrm{CO}_{2}\right)$ GHGs (e.g. chemical companies), and from less obvious sectors, such as the information technology industry (e.g. in the context of energy management and conservation).

While the trend in private-sector energy R\&D appears to have been largely downward over the last three decades, current private-sector R\&D investments relevant to energy technology are extremely difficult to assess, and these estimates provide a poor indication of the overall level of private-sector R\&D investment that could and likely will be brought to bear on the climate technology challenge (Newell, 2008). The innovative capacity of relevant industries is illustrated in Table 1, which shows $2006 \mathrm{R} \& \mathrm{D}$ expenditures (including as a percentage of sales) for the 1,250 companies that globally have the highest levels of R\&D investment (UK Department for Innovation, Universities and Skills, 2007). The list includes producers of transportation technologies - such as Ford, DaimlerChrysler, Toyota, Boeing, and Rolls-Royce - which have individual company R\&D budgets measured in billions of dollars per year and which together contribute to a global R\&D budget for the automotive sector of $\$ 80$ billion annually in 2006. Electronic and electrical equipment companies spent over $\$ 35$ billion in R\&D in 2006, including companies such as Siemens and Samsung, and general industrial companies, such as Mitsubishi Heavy Industries and General Electric, which have annual R\&D budgets of over \$11 billion globally. Newell (2009a) finds that, viewed from the standpoint of historic improvements in the efficiency of energy resource extraction and use, there are grounds for substantial optimism about the innovative potential of energy technology industries.

In the environmental literature, the relationship between innovation and policy has been explored under two broad themes. Early work focused on theoretical models to compare the effects of various environmental policy mechanisms (e.g. uniform standards, emissions taxes, or tradable permits) on environmentally friendly innovation. Many of these papers tend to predict that market-based policies, such as a tax or tradable permit, will induce more environmentally friendly innovation than uniform standards, although recent papers have shown that a precise ranking is theoretically ambiguous and depends on a number of factors (see, for example, Fischer et al., 2003). Importantly, there is also a distinction between how much innovation a particular policy induces and the overall dynamic efficiency of the policy, which will depend on the marginal benefits of emission reduction.

Empirical studies of the links between environmental policy and innovation were initially limited by a lack of data. Recently, as measures of innovative activity (e.g. patents) 
Table 1: R\&D expenditures for top R\&D-spending companies worldwide (for 2006, units as indicated)

\begin{tabular}{lrc}
\hline & \multicolumn{2}{l}{ R\&D } \\
\cline { 2 - 3 } Sector (number of companies) & US\$ (millions) & \% of sales \\
\hline All sectors (1,250) & 478,129 & 3.5 \\
Aerospace and defence (39) & 21,160 & 4.9 \\
Automobiles and parts (78) & 80,284 & 4.1 \\
Chemicals (91) & 22,341 & 3.1 \\
Construction and materials (23) & 2,374 & 0.9 \\
Electricity (16) & 2,918 & 0.9 \\
Electronic and electrical equipment (102) & 35,150 & 4.5 \\
Forestry and paper (8) & 573 & 0.5 \\
Gas, water, and multi-utilities (7) & 738 & 0.3 \\
General industrials (36) & 11,583 & 2.1 \\
Household goods (24) & 5,011 & 2.3 \\
Industrial engineering (70) & 11,737 & 2.7 \\
Industrial metals (23) & 3,201 & 0.8 \\
Industrial transportation (6) & 440 & 0.3 \\
Mining (3) & 604 & 0.7 \\
Oil and gas producers (18) & 6,465 & 0.3 \\
Oil equipment, services, and distribution (10) & 1,748 & 1.9 \\
Pharmaceuticals and biotechnology (157) & 92,881 & 15.9 \\
Software and computer services (113) & 34,359 & 10.1 \\
Technology hardware and equipment (207) & 84,517 & 8.6 \\
\hline
\end{tabular}

Note: Table includes sectors that may be relevant to GHG innovation, as well as certain very large R\&D-performing sectors, from the $R \& D$ Scorecard's 1,250 companies globally with the highest R\&D expenditures (UK Department for Innovation, Universities and Skills, 2007). These 1,250 companies account for about 80 per cent of global industry R\&D.

have become more readily available, empirical studies have begun to estimate the effects that energy prices and environmental policies have on environmentally friendly innovation.

\section{(i) Empirical evidence on induced innovation}

Economists have investigated this process of induced innovation for many years in the context of a broad set of industries, and more recent evidence supports the inducement mechanism specifically in the context of environmental and energy technology innovation in response to increases in cost of energy and environmental emissions (for surveys, see Jaffe et al., 2003; and Popp et al., 2009).

Henderson and Newell (2009) show that while federal policy can play an important role in shaping initial demand, the best guarantee of accelerated private investment in innovation is the expectation of rapidly growing demand for products based on those new technologies. They point out that rapidly growing demand plays two key roles in stimulating innovation. First and foremost, it signals a plausibly large market - something that greatly accelerates private-sector investment in innovation and the rapid diffusion of new technologies. Second, and perhaps more subtly, growing demand provides an important opportunity for immediate feedback from the market, whereby new product development underpins innovation that is 
more directly responsive to real market needs and less likely to fall prey to the isolation of the ivory tower.

Although it is difficult to measure directly the extent to which innovation has been induced, this mechanism has been approximated by economists in a number of relevant studies. For example, patents have been used to approximate innovation for a variety of countries (Lanjouw and Mody, 1996; Popp, 2002). These studies find that environmentally friendly innovation (measured by the number of relevant patents) increases as the cost of pollution abatement rises.

Patent data reveal that innovation responds rapidly to changing energy prices and government regulation. More than one-half of the full effect of an energy price increase on patenting in the field of alternative energy and energy efficiency technology was experienced after just 5 years in one study (Popp, 2002). Thus, prices (or other regulations that increase the cost of using fossil fuels) can be expected to stimulate new research quickly. This lag takes into account the quality of knowledge available to an inventor as well as other factors influencing R\&D, such as government support for energy research and technologyspecific demand shifters.

Short lag times are also evident in the effect of energy prices and energy efficiency standards on the menu of household consumer goods available for sale. For example, Newell et al. (1999) examined innovation in the energy efficiency of the menu of home appliances available for sale and tracked the changes in response to energy prices between 1958 and 1993. They found that within less than 5 years of regulatory and price changes, significant amounts of innovation were due to changes in energy prices, while changes in energy-efficiency standards limited the availability of low-efficiency models. The study also illustrates the importance of making information available to consumers, in this case in the form of energy-efficiency labelling requirements, which can increase the value of certain product characteristics by making consumers more aware of them. They found that the effect of energy-price increases on model substitution was strongest during the period after product labelling took effect.

Despite the connection of innovation to price signals and regulatory stringency, innovation in a given area does tend to exhibit a gradual decline after some point in its development, such as might be expected owing to diminishing returns (Popp, 2002, 2006b). On the one hand, the size of the existing knowledge base has a significant positive effect on energy and other patenting. On the other hand, as more and more discoveries are made in a particular area, it eventually tends to become harder to develop a new innovation that improves upon the existing technology. The relative balance between these countervailing forces is technology specific and evolves in a complex manner over time.

\section{(ii) Induced innovation and the choice of policy instrument}

Recent evidence supports the idea that environmental and energy technology innovation responds to increases in cost of energy and environmental emissions (for surveys, see Jaffe et al., 2003; and Popp et al., 2009). The economic literature makes clear the advantages of economy-wide, long-term, market-based emissions pricing for climate policy (for overviews see Kopp and Pizer, 2007; Metcalf, 2007; Stavins, 2007). Establishing a GHG emissions price is important, from a technology perspective, for two closely related reasons. First, the GHG price attaches a financial cost to GHGs and will induce households and firms to buy technologies with lower GHG emissions (a more efficient 
appliance, for example). The GHG price does not encourage just any technology adoption, but rather specifically guides the adoption of the most cost-effective technologies for reducing emissions by sending a consistent financial signal to households and businesses. Second, the GHG price creates a demand-driven, profit-based incentive for the private sector to invest effort in developing new, lower-cost climate-friendly innovations. Market-demand pull encourages manufacturers to invest in R\&D and other innovative efforts to bring new lower-GHG technologies to market, just as they do for other products and processes.

A core question is which policy instruments work best to induce innovation? An unambiguous ranking of policy instruments does not appear to be possible (Fischer et al., 2003). Rather, the ranking of policy instruments depends on the extent to which they allow innovators to appropriate spillover benefits of new technologies to other firms, the costs of innovation, environmental benefit functions, and the number of firms producing emissions. Policy instruments affect the innovation incentives primarily through three channels: (i) an abatement cost effect, reflecting the extent to which innovation reduces the costs of pollution control; (ii) an imitation effect, which weakens innovation incentives owing to imperfect appropriability; and (iii) an emissions payment effect, which can weaken incentives if innovation reduces firms' payments for residual emissions. The relative strength of these effects will vary across policy instruments and particular applications, with no instrument clearly dominating in all applications. Furthermore, in practice it will be even more difficult to rank competing policy instruments, which are in practice more complex and subject to a variety of additional practical considerations.

There are also important timing questions. When should different instruments be introduced, and in what order? These questions are significant because the optimal stringency of a policy may change as new abatement technologies become available. One theoretical model considered four options: (i) ex post regulation after adoption of new technology; (ii) interim regulation after observing $\mathrm{R} \& \mathrm{D}$ success but before adoption; (iii) ex ante regulation with different tax rates contingent on R\&D success; and (iv) ex ante regulation with a single tax rate, whether or not R\&D is successful (Requate, 2005). Of the four scenarios, Requate found that ex ante commitment with different tax rates depending on R\&D success dominated other policies.

Some policy instruments may induce innovation which reduces costs of compliance, while others may induce innovation that increases efficiency and overall abatement. The passage of the 1990 Clean Air Act (CAA) and the subsequent sulphur dioxide $\left(\mathrm{SO}_{2}\right)$ permit trading programme provided an excellent opportunity to study the effects of two contrasting types of regulation, explored most notably by Popp (2003) and Taylor et al. (2003). Before the 1990 CAA, most new coal-fired electric utilities were required to install flue-gas desulphurization (FGD) units, or 'scrubbers' with a removal efficiency of 90 per cent. Because installation was mandatory, innovation focused on reducing the operating costs of these units. However, because there were no incentives for firms to exceed the 90 per cent limit, innovation had no effect on the removal efficiency of FGD units. The number of patents on pre-combustion techniques for reducing $\mathrm{SO}_{2}$ emissions was likewise unremarkable during this time period. In contrast, after passage of the CAA-which required greater $\mathrm{SO}_{2}$ emissions reductions and gave firms flexibility as to how to meet those goals - post-1990 innovations did improve the removal efficiency of scrubbers.

The CAA example also highlights the innovation incentives produced by an expanded market for the abatement product. The permit trading system of the 1990 CAA provided, for the first time, incentives for older plants to install scrubbers. This expanded the market 
for scrubbers and increased incentives for technological change (Lange and Bellas, 2005). Indeed, both capital and operating expenses dropped for scrubbers installed after the 1990 CAA took effect.

The flexibility of the CAA is credited for its success in reducing $\mathrm{SO}_{2}$ levels. Flexible performance standards dictate an acceptable level of environmental performance, but do not dictate how that level need be achieved. In contrast, technology standards (such as mandatory scrubbers) require the use of a specific technology to meet regulatory targets. The experience of seven OECD countries is that more flexible performance standards induce more environmental R\&D than technology standards (Lanoie et al., 2007). In related work, Johnstone and Hascic (2008) show that flexible environmental regulations lead to higherquality innovation - environmental patents tend to have larger family sizes when there is greater freedom to choose different options in order to achieve compliance with environmental regulations. Greater stringency also tends to induce a firm to perform more environmental R\&D (Lanoie et al., 2007).

\section{The impacts of technological change on the environment}

The previous section focuses on the relationship between incentives (either market prices or policy) and the direction and level of technological change. This section briefly considers the effect of these new technologies on the environment. A natural starting hypothesis would be that environmental innovations should reduce the costs of pollution control and therefore increase the level of abatement and environmental protection.

There is some evidence to suggest that innovation does, indeed, reduce the cost of pollution control. Carlson et al. (2000) examine changes in the marginal cost of sulphur dioxide removal at power plants, and find that about 20 per cent, or $\$ 50$, of the change in marginal abatement costs that occurred from 1985 to 1995 can be attributed to technological change. Popp (2003) uses patent data to link innovative activity to lower operating costs of scrubbers for coal-fired electric power plants. A single patent provides a present value of about $\$ 6 \mathrm{~m}$ in cost savings across the industry. Assuming approximately $\$ 1.5 \mathrm{~m}$ of R\&D spent per patent granted, this yields a return similar to those found in the more general works in the technological change literature. However, these savings account only for the benefits to the power industry of lower environmental regulation compliance costs, as the social benefits of reduced $\mathrm{SO}_{2}$ emissions are not included in the estimate.

The effects of innovation on energy efficiency are clearer. Pakes et al. (1993) investigate the effects of gasoline prices on the fuel economy of motor vehicles offered for sale. They find that the observed increase in miles per gallon (mpg) from 1977 onwards was largely due to the consequent change in the mix of vehicles on the market. Fewer low-mpg cars and more high-mpg cars were marketed. Subsequently, Berry et al. (1996) found that qualityadjusted costs generally increased over the period 1972-82, coinciding with rising gasoline prices and emission standards.

In energy-intensive industries, implementation of new technology has a cost-savings effect that far outweighs the cost of R\&D devoted to the innovation. Patents reducing energy costs have generated $\$ 14.5 \mathrm{~m}$ dollars in long-run energy savings among a subset of industries (Popp, 2001) which spend an average of \$2.25 $\mathrm{m}$ of R\&D per patent. But a study of a wider set of industries suggests that while induced innovation does have an energy-saving effect, it is the smallest of four factors (Sue Wing, 2008). Likewise in the manufacturing 
sector, technology adoption explains just a small portion of changes in energy demand during the $1970 \mathrm{~s}$ and $1980 \mathrm{~s}$ (Linn, 2008).

\section{The role of government in supporting R\&D}

The previous sections have focused primarily on the incentives faced and activities conducted by private firms. However, governments also play an important role in energy R\&D. IEA member countries, which together account for about 85 per cent of overall global R\&D expenditures, spent an estimated $\$ 11$ billion on publicly funded energy R\&D in 2006 (IEA, 2007a) — or about 4 per cent of overall public R\&D spending by these countries in the same year. In the United States, about half of government funding is transferred to universities, other non-profit research institutions, and industry, which perform the associated R\&D within a system of contracts, grants, and other arrangements. Government funding tends to focus more on basic and applied research.

In addition to creating new knowledge upon which further technological development can draw, university-based R\&D supports the production of young researchers. Most of these researchers eventually move into the private sector - thus they represent an important link within the overall innovation system. Ensuring a stream of scientists, engineers, and other research professionals trained in areas relevant to clean-energy technologies can increase the necessary innovative effort and moderate its cost. The capacity of a country's workforce to absorb and apply new know-how and technology is also essential for development, and it is one of the main impediments to more rapid technology transfer to developing countries (World Bank, 2008).

By supporting researchers and graduate students, public funding for research affects an economy's capacity to generate and assimilate scientific advances, technology innovations, and productivity improvements. This linkage has made research funding a priority among many who are concerned about the long-term competitiveness of national economies and has led to increased support for expanded R\&D spending generally, including in the United States and the European Union. At an international level, programmes that facilitate the international exchange of graduate students, post-docs, and more senior scholars in areas relevant to climate-mitigation research may help to expand human-capital-related spillovers.

Government investment plays another important role: it can help to compensate for underinvestment by private firms. Unlike firms, the government is in position to consider social returns when making investment decisions. In addition, government R\&D tends to have different objectives from private R\&D. Government support of basic R\&D is particularly important, as long-term payoffs, greater uncertainty, and the lack of a finished product at the end all make it difficult for private firms to appropriate the returns of basic R\&D. Thus, the nature of government R\&D is important. For example, Popp (2002) finds that government energy R\&D served as a substitute for private energy R\&D during the $1970 \mathrm{~s}$, but as a complement to private energy $R \& D$ afterwards. One explanation given for the change in impact is the changing nature of energy R\&D. During the $1970 \mathrm{~s}$, much government R\&D funding went to applied projects, such as the effort to produce synfuels. During the $1980 \mathrm{~s}$ and thereafter, government energy R\&D shifted towards a focus on more basic applications.

Whether government $\mathrm{R} \& \mathrm{D}$ is always socially productive is less clear, although it should not be expected that all research will generate useful results. Cohen and Noll (1991) docu- 
mented the waste associated with the breeder reactor and synthetic fuel programmes in the 1970 s, but in the same volume Pegram (1991) concluded that the photovoltaics research programme undertaken in the same time frame had significant benefits. More recently, the US National Research Council (NRC) attempted a fairly comprehensive overview of energy efficiency and fossil energy research at US Department of Energy (DOE) over the last two decades (NRC, 2001). Using both estimates of overall return and case studies, they concluded, as one might expect, that there were only a handful of programmes that proved highly valuable. Their estimates of returns suggest, however, that the benefits of these successes justified the overall portfolio investment.

In addition to correcting for underinvestment by private firms, many government R\&D projects aim to improve commercialization of new technologies (referred to as 'transfer' from basic to applied research). Such projects typically combine basic and applied research and are often done through government/industry partnerships (National Science Board, 2006). For example, the United States passed several policies in the 1980 s specifically designed to improve transfer from the more basic research done at government and university laboratories to the applied research done by industry to create marketable products. As such, this technology transfer can be seen as a step between the processes of invention and innovation. The $1980 \mathrm{~s}$ policies have resulted in greater innovation, as measured by patents (Jaffe and Lerner, 2001). A study by Popp (2006b) further suggests that government $R \& D$ has an effect. His examination of citations made to patents in 11 energy technology categories (such as wind and solar energy) reveals that energy patents spawned by government R\&D are cited more frequently than other energy patents. This is consistent with the notion that these patents are more basic. More importantly, after passage of the technology transfer acts in the early $1980 \mathrm{~s}$, the children of these patents (that is, privately held patents that cite government patents) are the most frequently cited patents, suggesting that transferring research results from the government to private industry produces valuable research results.

Beyond traditional research contracts and grants, prizes for climate-change-related innovation have received attention more recently. The idea is to offer financial or other rewards for achieving specific innovation objectives that have been specified in advance (Newell and Wilson, 2005; Kalil, 2006; NRC, 2007; Brunt et al., 2008). Prizes of this type can help focus research efforts on clearly defined objectives, instill a sense of urgency and competition, and engage a broad set of innovators (Newell, 2008).

International technology-oriented agreements also have the potential to play an important role in the architecture of an international climate change policy (Newell, 2009b; de Coninck et al., 2008; Justus and Philibert, 2005). The range of opportunities for improving and expanding international climate technology development and transfer also extends well beyond the usual boundaries of environmental decision-makers to the broader context of international agreements and institutions for energy, trade, development, and intellectual property (Newell, 2009b). Specific activities under such agreements could include knowledge sharing and coordination, joint R\&D, technology transfer, and/or technology deployment mandates or incentives. Many of these activities could lower the costs of mitigation technologies, resulting in the greater likelihood that countries could implement significant GHG reductions. For example, Justus and Philibert highlight a number of case studies in which collaboration helped advance technology innovation and reduce costs through collaboration. The tension between collaboration and competition is often evident in such efforts, however, as it is with private research consortia. 


\section{Complementarities between environmental and technology policies}

Environmental and technology policies work best in tandem. While R\&D policy can help facilitate the creation of new environmentally friendly technologies, it provides little incentive to adopt these technologies. For example, a study by Fischer (2008) shows that government support for emissions control R\&D is only effective if there is at least moderate environmental policy in place to encourage adoption of the resulting technologies. Bosetti et al. (2009) similarly show that $\mathrm{R} \& \mathrm{D}$ alone is insufficient to stabilize $\mathrm{CO}_{2}$ levels without an accompanying carbon tax. Popp (2006a) considers the long-run welfare gains from both an optimally designed carbon tax (one equating the marginal benefits of carbon reductions with the marginal costs of such reductions) and optimally designed R\&D subsidies. He finds that combining both policies yields the largest welfare gain. However, the policies do not contribute equally. A policy using only the carbon tax achieves 95 per cent of the welfare gains of the combined policy, while a policy using only the optimal R\&D subsidy attains just 11 per cent of the welfare gains of the combined policy in his model. Similarly, Parry et al. (2003) find that the efficiency gains from correcting the R\&D market failure appear to be smaller than those from correcting the $\mathrm{CO}_{2}$ emissions externality.

The above studies focus on the aggregate level, and assume that technologies, once created, are optimally deployed. Fischer and Newell (2008) study a broader set of policies, including technology adoption policies. They evaluate the relative performance of policies according to incentives provided for emissions reduction and economic efficiency, and they also assess how the nature of technological progress (i.e. learning versus R\&D) and the degree of knowledge spillovers, affects the desirability of different policies. Although the relative cost of individual policies in achieving emissions reductions depends on parameter values and the emissions target, in a numerical application to the US electricity sector, they find the ranking in terms of cost-effectiveness is roughly as follows: (i) emissions price, (ii) emissions performance standard, (ii) fossil power tax, (iv) renewables share requirement, (v) renewables subsidy, and (vi) R\&D subsidy. Nonetheless, an optimal portfolio of policiesincluding emissions pricing to correct the environmental externality, deployment incentives to internalize learning spillovers, and R\&D to address R\&D spillovers - in principle can achieve emission reductions at significantly lower cost than any single policy.

In a similar exercise, Gerlagh and van der Zwaan (2006) find an emissions performance standard to be the most cost-effective policy for achieving various carbon stabilization goals. They note that, like a carbon tax, the emissions performance standard directly addresses the environmental externality. In addition, because performance standards implicitly subsidize output like a renewable subsidy, the emissions performance standard can stimulate innovation in a sector with high spillovers. In comparing the results of these two papers, Gerlagh and van der Zwaan note that the ordering of policies therefore depends on the assumed returns to scale of renewable energy technologies. Fischer and Newell assume a greater degree of decreasing returns, owing to the scarcity of appropriate sites for new renewable sources. Thus, an important question raised by Gerlagh and van der Zwaan is whether cost reductions through innovation will be sufficient to overcome eventual decreasing returns to scale for renewable energy.

An additional problem resulting from the long time frame of environmental concerns such as climate change is uncertainty over future policies. For market-based GHG emissions policy to provide an effective inducement to innovation, it is critical that the policy be credible 
to the private sector over the long term (Helm et al., 2003). Given the sometimes substantial time lags between initial discovery and profitable market penetration, companies must be confident there will, indeed, be sufficient demand once their innovations reach the market. Such long-term issues arise often when studying problems such as climate change, and they raise the question of whether additional policy measures are needed that (i) enable the government to establish strong expectations of future prices, or (ii) perform the initial research necessary to get ground-breaking technologies close to market, thus lowering the cost of future environmental policy. A related concern that has been raised is the credibility of governments to use the promise of high future emissions prices to boost current innovation, since such high prices may no longer be needed once the resulting cost reductions arrive (Kennedy and Laplante, 1999; Montgomery and Smith, 2007).

To address these concerns, Newell (2008) points out that it would therefore be critical for policy-makers to put in place GHG emissions pricing policies whose stringency is spelled out for many decades in advance, and that provide stable financial incentives across a wide array of technological solutions. One option for providing such credibility is an economywide cap-and-trade system or carbon tax, with no expiration date, increasingly stringent targets specified through several decades, and an architecture with sufficient flexibility to adjust over time. Under a cap-and-trade system, allowance prices and corresponding financial incentives for technology could also be stabilized through flexibility over time (i.e. through emissions banking and borrowing) and through provisions for price floors and price ceilings on emissions allowances (Murray et al., 2009; Newell et al., 2005).

General purpose technologies (GPTs) may also magnify the interaction between the two market failures. GPTs are technologies that find use in many distinct application sectors within the economy, such as the electric motor, the steam engine, the internal combustion engine, semiconductors, and the Internet (Bresnahan and Trajtenberg, 1995). The development of such technologies increases the returns to R\&D designed to incorporate them into the different applications sectors; development of such applications in turn increases the return to improving the GPT. Because of these dynamic feedback effects, GPTs may be an important factor in economic growth (Helpman, 1998). The dynamic feedback between a GPT and its applications sectors also creates an important example of 'path dependence'. These phenomena can be critical to understanding the existing technological system, forecasting how that system might evolve, and predicting the potential effect of some policy or event. With respect to the environment, whether the GPTs that drive a particular era are pollution-intensive or pollution-reducing may have profound implications for the long-term environmental prognosis. If GPTs are pollution-intensive, for example, it would tend to raise the cost of attaining a clean environment and lower the extent of environmental protection, other things equal.

\section{Conclusions}

Technological change plays an important role in climate change policy. While new technologies can make cleaner production and more efficient resource use possible, markets are unlikely to provide proper incentives for the development of no- or low-carbon technologies, absent public policy. As in other areas of technological change, knowledge spillovers lead to underinvestment in R\&D by private firms. However, even if all knowledge market failures were addressed, firms would still underinvest in environmental $R \& D$, as most of the benefits 
to providing a cleaner environment are external to the firm. By addressing the externality problem, environmental policy increases incentives for environmental R\&D. Economic theory and empirical analysis therefore clearly suggest a combination of both emissions policy and innovation policy is required to provide an efficient response to the climate problem, which involves both environmental externalities as well as technology spillovers.

Broad GHG pricing has two benefits from a technology perspective. First, attaching a financial cost to GHGs would induce households and firms to buy technologies with lower GHG emissions. An economy-wide GHG price would likely encourage the adoption of the most cost-effective technologies for reducing emissions by sending a consistent financial signal to households and businesses across the economy. Second, credible GHG pricing would create a demand-driven, profit-based incentive for the private sector to invest effort in developing new, lower-cost climate-friendly innovations (for surveys see Jaffe et al., 2003, and Popp et al., 2009). In particular, flexible environmental policy instruments that provide rewards for continual environmental improvement and cost reduction, rather than specifying particular behaviour or locking in particular technologies, unsurprisingly have better dynamic efficiency.

As with environmental innovation, studies on the diffusion of environmental technologies also find that environmental regulation or technology deployment incentives are necessary for diffusion to occur. One notable difference is between environmental technologies (e.g. pollution control) and energy-efficiency technologies. Without environmental regulation, there is little private benefit to pollution control. Thus, as expected, regulation is necessary for diffusion to occur. On the other hand, individual consumers or firms can benefit from choosing energy-efficient technologies, as adopters benefit from lower energy bills. However, research on the adoption of energy-efficiency technologies suggests that decision-making by both firms and consumers is subject to potential market and behavioural failures (Gillingham et al., 2009).

More broadly, recent work by a number of innovation economists (Henderson and Newell, 2009) suggests that an effective innovation system has three key elements: (i) accelerating demand for new technology; (ii) institutions that support abundant generation and dissemination of fundamental scientific and technical knowledge; and (iii) a vibrant, competitive private sector. The histories in that volume also highlight the role that public policy has played in building and/or sustaining all three elements. First, public policy has often stimulated demand, particularly in the early stages of a technology's evolution. Second, publicly funded basic research has had a dramatic effect when it is structured in a way that it is 'creative', 'linked', and when it trains the scientific and technical workforce that ultimately populates the private sector. Third, a mix of public policies-including procurement, antitrust, and intellectual property protection-played an important role in several industries by encouraging extensive competition and entry by new founded firms.

In recent years, researchers have also begun to investigate the role of international technology diffusion for environmental technologies. International diffusion is particularly important for problems such as climate change, as carbon emissions are growing faster in developing nations than in the developed world. Recent research suggests that these developing countries can take advantage of clean technologies developed in high-income countries, but that both environmental and trade policies will affect the pace and quality of international technology diffusion. The range of opportunities for improving and expanding international climate technology development and transfer could include a broad array of international agreements and institutions for energy, trade, development, and intellectual property. Specific activities under such agreements could include knowledge sharing and coordination, joint R\&D, technology transfer, financing mechanisms, liberalization of trade in environmental technologies, and treatment of intellectual property. 
A well-targeted set of climate policies, including those targeted directly at science and innovation, could help lower the overall costs of mitigation. It is important to stress, however, that poorly designed technology policy could raise rather than lower the societal costs of climate mitigation. To avoid this, policy could create substantial incentives in the form of a market-based price on GHG emissions, and directed government technology support could emphasize areas least likely to be undertaken by the private sector. This would tend to emphasize strategic basic research that advances science in areas critical to climate mitigation. In addition to generating new knowledge and useful tools, such funding also serves the critical function of training the next generation of scientists and engineers for future work in the private sector, at universities, and in other research institutions.

Effective and efficient climate technology policy would tend to complement rather than substitute for emissions pricing. On the research side, R\&D without market demand for the results is like pushing on a rope, and would ultimately have little impact. On the deployment side, technology-specific mandates and subsidies tend to generate emissions reductions in a relatively inefficient manner relative to an emissions price, and under an economy-wide capand-trade system would not actually generate any additional reductions. The scale of the climate technology problem and other energy challenges tends to point to a solution that would maximize the impact of the scarce resources available for addressing these and other critical societal goals.

\section{References}

Arrow, K. J., Cohen, L., David, P. A., Hahn, R. W., Kolstad, C. D., Lane, L., Montgomery, W. D., Nelson, R. R., Noll, R. G., and Smith, A. E. (2009), 'A Statement on the Appropriate Role for Research and Development in Climate Policy', The Economists' Voice, 6(1), Article 6.

Berry, S., Kortum, S., and Pakes, A. (1996), 'Environmental Change and Hedonic Cost Functions for Automobiles', Proceedings of the National Academy of Sciences, USA, 93, 12731-8.

Bosetti, V., Carraro, C., Duval, R., Sgobbi, A., and Tavoni, M. (2009), 'The Role of R\&D and Technology Diffusion in Climate Change Mitigation: New Perspectives Using the WITCH Model', OECD Economics Department Working Papers, No. 664, Paris, Organization for Economic Cooperation and Development.

Bresnahan, T. J., and Trajtenberg, M. (1995), 'General Purpose Technologies: “Engines of Growth”?', Journal of Econometrics, 95, 83-108.

Brunt, L., Lerner, J., and Nicholas, T. (2008), 'Inducement Prizes and Innovation', CEPR Discussion Paper No. DP6917.

Carlson, C., Burtraw, D., Cropper, M., and Palmer, K. (2000), 'Sulfur Dioxide Control by Electric Utilities: What are the Gains from Trade?', Journal of Political Economy, 108, 1292-326.

Clarke, L. E., Wise, M., Placet, M., Izaurralde, C., Lurz, J., and Kim, S. et al. (2006), 'Climate Change Mitigation: An Analysis of Advanced Technology Scenarios', Pacific Northwest National Laboratory, Richland, WA.

Cohen, L. R., and Noll, R. G. (1991), The Technology Pork Barrel, Brookings, Washington, DC.

de Coninck, H., Fisher, C., Newell, R. G., and Ueno, T. (2008), 'International Technology-oriented Agreements to Address Climate Change', Energy Policy, 36, 335-56.

Fischer, C. (2008), 'Emissions Pricing, Spillovers, and Public Investment in Environmentally Friendly Technologies', Energy Economics, 30(2), 487-502.

- Newell, R. G. (2008), 'Environmental and Technology Policies for Climate Mitigation', Journal of Environmental Economics and Management, 55(2), 142-62. 
— Parry, I. W. H., and Pizer, W. A. (2003), 'Instrument Choice for Environmental Protection when Technological Innovation is Endogenous', Journal of Environmental Economics and Management, 45(3), 523-45.

Gerlagh, R., and van der Zwaan, B. C. C. (2006), 'Options and Instruments for a Deep Cut in CO2 Emissions: Carbon Capture or Renewables, Taxes or Subsidies?', Energy Journal, 27, 25-48.

Gillingham, K., Newell, R. G., and Palmer, K. (2009), 'Energy Efficiency Economics and Policy', manuscript prepared for the Annual Review of Resource Economics.

- Pizer, W. A. (2008), 'Modeling Endogenous Technological Change for Climate Policy Analysis', Energy Economics, 30(6), 2734-53.

Goulder, L. H. (2004), Induced Technological Change and Climate Policy, Washington, DC, Pew Center on Global Climate Change.

Helm, D., Hepburn, C., and Mash, R. (2003), 'Credible Carbon Policy', Oxford Review of Economic Policy, 19(3), 438-50.

Helpman, E., (ed.) (1998), General Purpose Technologies and Economic Growth, Cambridge, MA, MIT Press.

Henderson, R., and Newell, R. G. (2009), 'Accelerating Energy Innovation: Lessons from Multiple Sectors', forthcoming NBER volume by University of Chicago Press.

IEA (2007a), Energy Technology RD\&D Budgets 2007, Paris, Organization for Economic Cooperation and Development/International Energy Agency.

- (2007b), World Energy Outlook 2007, Paris, Organization for Economic Cooperation and Development/ International Energy Agency.

- (2008), Energy Technology Perspectives 2008, Paris, Organization for Economic Cooperation and Development/International Energy Agency.

Jaffe, A. B., and Lerner, J. (2001), 'Reinventing Public R\&D: Patent Policy and the Commercialization of National Laboratory Technologies', RAND Journal of Economics, 32(1), 167-98.

— Newell, R. G., and Stavins, R. N. (2003), 'Technological Change and the Environment', in K.-G. Mäler and J. Vincent (eds), Handbook of Environmental Economics, Vol. 1, Amsterdam, North-Holland/Elsevier, 461-516.

_ _ _ (2005), 'A Tale of Two Market Failures: Technology and Environmental Policy', Ecological Economics, 54, 164-74.

Johnstone, N., and Hascic, I. (2008), 'Environmental Policy Design and the Fragmentation of Markets for Innovation', paper presented at the Venice Summer Institute 2008 Workshop on 'Reforming Rules and Regulations-Laws, Institutions and Implementation', Venice, 19 July.

Justus, D., and Philibert, C. (2005), 'International Energy Technology Collaboration and Climate Change Mitigation: Synthesis Report', COM/ENV/EPOC/IEA/SLT(2005)11, Paris, Organization for Economic Cooperation and Development.

Kalil, T. (2006), 'Prizes for Technological Innovation', Hamilton Project Discussion Paper 2006-08, Washington, DC, Brookings Institution.

Kennedy, P. W., and Laplante, B. (1999), 'Environmental Policy and Time Consistency: Emissions Taxes and Emissions Trading', in E. Petrakis, E. Sartzetakis, and A. Xepapadeas (eds), Environmental Regulation and Market Power: Competition Time Consistency and International Trade, Northampton, MA, Edward Elgar.

Kopp, R. J., and Pizer, W. A. (eds) (2007), 'Assessing US Climate Policy Options', Washington, DC, Resources for the Future.

Lange, I., and Bellas, A. (2005), 'Technological Change for Sulfur Dioxide Scrubbers Under Market-based Regulation', Land Economics, 81(4), 546-56.

Lanjouw, J. O., and Mody, A. (1996), 'Innovation and the International Diffusion of Environmentally Responsive Rechnology', Research Policy, 25, 549-71.

Lanoie, P., Laurent-Lucchetti, J., Johnstone, N., and Ambec, S. (2007), 'Environmental Policy, Innovation and Performance: New Insights', GAEL Working Paper 2007-07.

Linn, J. (2008), 'Energy Prices and the Adoption of Energy Saving Technology', The Economic Journal, 118 (533), 1986-2012.

Manne, A, and Richels, R. (1992), Buying Greenhouse Insurance, Cambridge, MA, MIT Press. 
Metcalf, G. E. (2007), ‘A Proposal for a US Carbon Tax Swap', Hamilton Project Discussion Paper 2007-12, Washington, DC, Brookings Institution.

Montgomery, W. D., and Smith, A. E. (2007), 'Price, Quantity and Technology Strategies for Climate Change Policy', in M. E. Schlesinger et al. (eds), Human-induced Climate Change: An Interdisciplinary Assessment, Cambridge, Cambridge University Press.

Murray, B., Newell, R. G., and Pizer, W. A. (2009), 'Balancing Cost and Emissions Certainty: An Allowance Reserve for Cap-and-trade', Review of Environmental Economics and Policy, 3(1), 84-109.

National Science Board (2006), 'Science and Engineering Indicators 2006', National Science Foundation, Chapter 4: Research and Development: Funds and Technology Linkages, Arlington, VA.

Newell, R. G. (2008), 'A US Innovation Strategy for Climate Change Mitigation', Hamilton Project Discussion Paper 2008-15, Washington DC, Brookings Institution.

— (2009a), 'The Energy Innovation System: A Historical Perspective', forthcoming in R. Henderson and R. G. Newell (eds), Accelerating Energy Innovation: Lessons from Multiple Sectors, NBER volume by University of Chicago Press.

- (2009b), 'International Climate Technology Strategies', in J. E. Aldy and R. N. Stavins (eds), PostKyoto International Climate Policy: Implementing Architectures for Agreement, Cambridge, Cambridge University Press.

- Wilson, N. (2005), 'Technology Prizes for Climate Change Mitigation', Resources for the Future Discussion Paper No.05-33.

— Jaffe, A. B., and Stavins, R. N. (1999), 'The Induced Innovation Hypothesis and Energy-saving Technological Change', Quarterly Journal of Economics, 114(3), 941-75.

— Pizer, W. A., and Zhang, J. (2005), 'Managing Permit Markets to Stabilize Prices', Environmental and Resource Economics, 31, 133-57.

NRC (2001), Energy Research at DOE: Was it Worth It?, National Research Council, Washington, DC, National Academies Press.

- (2007), Innovation Inducement Prizes at the National Science Foundation, National Research Council, Washington, DC, National Academies Press.

OECD (2008), Main Science and Technology Indicators, Volume 2008/1, Paris, Organization for Economic Cooperation and Development.

Pakes, A., Berry, S., and Levinsohn, J. A. (1993), 'Applications and Limitations of Some Recent Advances in Empirical Industrial Organization: Prices Indexes and the Analysis of Environmental Change', American Economic Review, 83, 240-6.

Parry, I. W. H., Pizer, W. A., and Fischer, C. (2003), 'How Large are the Welfare Gains from Technological Innovation Induced by Environmental Policies?', Journal of Regulatory Economics, 23, 237-55.

Pegram, W. M. (1991), 'The Photovoltaics Commercialization Program', in L. Cohen and R. Noll (eds), The Technology Pork Barrel, Washington, DC, Brookings Institution.

Popp, D. (2001), 'The Effect of New Technology on Energy Consumption', Resource and Energy Economics, 23(3), 215-39.

- (2002), 'Induced Innovation and Energy Prices', American Economic Review, 92(1), 160-80.

- (2003), 'Pollution Control Innovations and the Clean Air Act of 1990', Journal of Policy Analysis and Management, 22, 641-60.

- (2006a), 'R\&D Subsidies and Climate Policy: Is there a "Free Lunch"?', Climatic Change, 77(3-4), $311-41$.

- (2006b), 'They Don't Invent them Like they Used to: An Examination of Energy Patent Citations over Time', Economics of Innovation and New Technology, 15(8), 753-76.

- Newell, R. G., and Jaffe, A. B. (2009), 'Energy, the Environment, and Technological Change', NBER Working Paper 14258, Cambridge MA.

Requate, T. (2005), 'Timing and Commitment of Environmental Policy, Adoption of New Technology, and Repercussions on R\&D', Environmental and Resource Economics, 31, 175-99.

Stavins, R. N. (2007), 'A US Cap-and-trade System to Address Global Climate Change', Hamilton Project Discussion Paper 2007-13, Washington, DC, Brookings Institution.

Sue Wing, I. (2008), 'Explaining the Declining Energy Intensity of the US Economy', Resource and Energy Economics, 30(1), 21-49. 
Taylor, M. R., Rubin, E. S., and Hounshell, D. H. (2003), 'Effect of Government Actions on Technological Innovation for $\mathrm{SO}_{2}$ Control', Environmental Science and Technology, 37, 4527-34.

UK Department for Innovation, Universities and Skills (2007), 'The 2007 R\&D Scoreboard', London, Department for Innovation, Universities and Skills.

UNFCCC (2007), Investment and Financial Flows to Address Climate Change, Bonn, United Nations Framework Convention on Climate Change.

World Bank (2008), Global Economic Prospects: Technology Diffusion in the Developing World, Washington, DC, World Bank. 
Copyright of Oxford Review of Economic Policy is the property of Oxford University Press and Oxford Review of Economic Policy Limited and its content may not be copied or emailed to multiple sites or posted to a listserv without the copyright holder's express written permission. However, users may print, download, or email articles for individual use. 